\title{
FACTORS CONSTRAINING FARMERS USE OF IMPROVED COWPEA TECHNOLOGIES IN BAUCHI AND GOMBE STATES OF NIGERIA
}

\author{
A. E. Agwu and A. C. Anyanwu \\ Department of Agricultural lixtension \\ University of Nigeria, Nsukka.
}

\begin{abstract}
This paper investigated major factors constraining the use of improved cowpea technologies among farmers in Bauchi and Gombe states of Nigeria. A structured interview schedule was used to collect data from a randomly selected sample of 130 farmers. Data were factor analyzed using the principal factor model with iteration and varimax rotation. The results show that land and labour problems, marketing problems, poor technical information, cultural incompatibility, high cost of farm inputs and unavailability of necessary inputs were the major factors constraining the use of improved cowpea technologies in the area. These findings suggest that there is an urgent need for researchers, policy makers and administratoms of extension service to consider these factors seriously, if increased cowpea production is to be achieved by farmers in the area.
\end{abstract}

Keywords: Cowpea, technologies, Bauchi, Gombe

\section{INTRODUCTION}

Cowpea (Vigna unguiculata (L.) Walp) is an important source of cheap dietary protein and other nutrients in most developing countries of the world where animal protein are beyond the financial reach of a large segment of the population (Anazonwu-Bello, 1976).

As food, cowpea constitutes a regular part of the diet and provides a major part of the protein requirements of the rural people (Prince et al, 1986; Quin, 1997). In fresh form, the young leaves, immature pods and peas are used as vegetable, while several snacks and main dishes are prepared from the grain. In addition, because the grain is widely sold out of the major production areas, it provides cheap protein for relatively poor urban communities as well as income for the farmers.

However, despite the value of this legume, its maximum contribution to mankind has not been fully exploited by farmers due to low pro- ductivity problems. The low production estimates of farmers that range from $<100$ to $330 \mathrm{~kg} \mathrm{ha}^{-1}$ (Rachie, 1985; Mortimore et al., 1997), are linked with unimproved varieties cultivated, heavy biotic pressures, sub-optimal planting dates, low plant population and low soils fertility status.

To overcome these problems, the International Institute of Tropical Agriculture (IITA) in collaboration with the Institute for Agricultural Research (IAR), Zaria developed the multiple disease and pest-resistant, high-yielding varieties and short duration strains together with more efficient production practices designed for a broad range of growing conditions (Singh and Ntare, 1985; IITA, 1993).

According to Fadiji et al (1996), the Agricultural Extension Services of the Institute for Agricultural Research and the States' Agricultural Development Programme have since 1988 been disseminating research results on these innovations to cowpea farmers. Unfortunately, available data show that the expected increase in productivity as a result of the advantages of- 
fered by the use of these inproved cowpen technolugies have not heen realised (FOS, 1995 and 1996). 'These suggest that lamers are not using these technologies.

The objective of this study was therefore to ascertain the major factors constraining the use of these improved cowpea technologies among larmers in Bauchi and Gombe States of Nlgerla.

\section{MATERIALS AND METHOD}

The study was conducted in Bauchi and Gombe States of Nigeria. The two states have a combined population of 4.2 million (FOS, 1996), and combined land area of $64,605 \mathrm{~km}^{2}$. Average population density is 65 persons per $\mathrm{km}^{2}$. The mean annual rainfall ranges between $1000 \mathrm{~mm}$ and 1500mm (Shaib et al., 1997). The two states linve simflar ecological fentures and fall within the sub-humid sub-zone of the North East Savanua Zone of Nigeria.

Seven Extension Blocks (EBs) were randomly selected out of the filty-seven EBs in Bauchi State, while six EBs were randomly selected out of the fifty-two EBs in Gombe State. From each block 10 to 12 farmers were randomly selected for interview. In all 145 cowpea farmers were sampled. A structured interview schedule was used for data collection. Only 130 correctly filled interview schedules were used for analysis.

To determine the magnitude of the constraints as perceived by the farmers, a five point Likert-type scale was utilized. The response options ranged from "not at all" to "to a very great extent" scaled 1 to 5 respectively. The improved cowpen technolagies included in the study, were the use of improved cowpea varieties, hiring/use of tractors for land preparation, use of correct spacing (inter-row $75 \mathrm{~cm}$, and within-row 20 $30 \mathrm{~cm}$ ), application of fertilizer (single super phosphate) before planting, and use of herbicides for weed control (Harkness et al., Fadiji et al., 1996). Others include, spraying with fungicides five weeks after sowing to control diseases, application of single super phosphate fertilizer at $200 \mathrm{~kg} / \mathrm{ha}$ of cowpea farmland and spraying of insecticides during the post flowering period to control pests on cowpea farms (Harkness et al., 1984; Fadiji et al., 1996).

Factor analysis, using the principal factor model whth lemalon and varimax rotalion was used to determine major variables constraining the use of improved cowpea technologies. The loadings under cach factor (bela weights) repre.. sent a correlation of the identified constraint factor and has the same interprelation as any correIntlon coefficient. Kniser's criterion using factor loadings above 0.30 was adopled in naming and interpreting the factors and constraint variables (Child, 1978; Madukwe, 1996; Agwu and Anyanwu, 1996).

\section{RESULTS AND DISCUSSION}

\section{Factors constraining the use of Improved Cowpea Technologies}

\section{Environmental Factors}

Data on Table 1 show the environmental factors constraining improved cowpea technologies based on the loading of issues, under the two extracted factors. Factor I was named "land and labour problems" while factor 2 was named "marketing problems"

Factor 1 "land and labour problems" was dominated by unavailability of labour required to carryout essential farming activities $(0.68)$, low soil fertility $(0.67)$, high cost of hired labour $(0.60)$, scarcity of farm land $(0.52)$ and drought problems (0.50). Pierce (1990) observed that the quantity and quality of resources (land, labour, and capital), and the availability of technology provide the impetus for growth when optimum or constrain when sub-optimum with the food system. However, the land and labour problems of the farming communities show the lack of optimum conditions necessary for increased production of the crop (cowpea).

The loadings under marketing problems include, lack of ready market for improved cowpea technology products $(0.84)$, low consumer preferences associated with improved cowpea produce $(0.71)$ and unavailability of good storage facilities $(0.63)$. Unlike the local cowpea varieties, which are late-maturing and mostly harvested during the dry season, most improved cowpea varieties are short-duration types which 


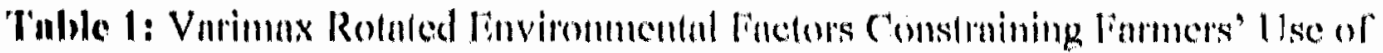
lmproved Cowpea T'echnologies

\begin{tabular}{|c|c|c|}
\hline Envirommental-Relaled Variables & $\begin{array}{l}\text { Factor } 1 \\
\text { (1, and and l anhour } \\
\text { Problems) }\end{array}$ & $\begin{array}{l}\text { Pnctor } 2 \\
\text { (Markeling } \\
\text { Problems) }\end{array}$ \\
\hline Scarcity of farm land. & 0.52 & 0.24 \\
\hline $\begin{array}{l}\text { Low soll fertlilty. } \\
\text { Unavailability of labour required to } \\
\text { carryout essential farming activities. }\end{array}$ & $\begin{array}{l}0.67 \\
0.68\end{array}$ & $\begin{array}{l}-0.01 \\
-0.18\end{array}$ \\
\hline High cost of hired labour in the area. & 0.60 & -0.55 \\
\hline Drought problems (lack of rains). & 0.50 & 0.16 \\
\hline $\begin{array}{l}\text { Lack of ready market for improved } \\
\text { cowpea technology products. }\end{array}$ & 0.20 & 0.84 \\
\hline $\begin{array}{l}\text { Unavailability of good storage } \\
\text { facilities. }\end{array}$ & 0.10 & 0.63 \\
\hline $\begin{array}{l}\text { Low consumers' preferences associaled } \\
\text { with improved cowpea products. }\end{array}$ & -0.10 & 0.71 \\
\hline
\end{tabular}

Table 2: Varimax Rotated Cultural Factors Constraining Farmers' Use of Improved Cowpen Technologies

\begin{tabular}{lcc}
\hline Socio-Cultural Related Variables & $\begin{array}{c}\text { Factor 1 } \\
\text { (Poor Technical } \\
\text { Information) }\end{array}$ & $\begin{array}{c}\text { Factor 2 } \\
\text { (Cultural } \\
\text { Incompatibility) }\end{array}$ \\
\hline $\begin{array}{l}\text { Difliculty in integrating technology into } \\
\text { existing production systems. }\end{array}$ & 0.18 & 0.72 \\
$\begin{array}{l}\text { Lack of adequate technical knowledge } \\
\text { in the use of improved cowpea }\end{array}$ & 0.87 & 0.10 \\
$\begin{array}{l}\text { technologies. } \\
\text { Conflict between technology and the }\end{array}$ & & \\
norms of the people. & 0.19 & \\
$\begin{array}{l}\text { Pour stornge of seedis of' linproved } \\
\text { cowpea varieties. }\end{array}$ & $-(0.05$ & 0.47 \\
$\begin{array}{l}\text { ligh incidence of pests (insects) altacks } \\
\text { on improved cowpea varieties. }\end{array}$ & -0.28 & 0.61 \\
$\begin{array}{l}\text { Lack of contact with important } \\
\text { information sources on improved } \\
\text { cowpea technologles. }\end{array}$ & 0.70 & 0.27 \\
$\begin{array}{l}\text { Complexity of improved cowpea } \\
\text { technologies. }\end{array}$ & & 0.07 \\
\hline
\end{tabular}


mature at the peak of the rainy season. This necessitates immediate disposal of the produce. llowever, the high moisture content of cowpen sceds harvested at this time, makes its disposal in llie markel very diflicult due to low consumser preferences associated with them. Again, seeds larvested during this period common be eflectively stored with the available storage facilities due to their high moisture content. $\Lambda$ gboola (1980) and Okuneye (1994) have pointed out the urgent need to match all efforts geared towards increased production with adequate and efficient stornge facilities to save the crops that are produced from deterioration and waste.

\section{Cultural Factors}

Table 2 shows the loading of items under the two extracted factors. Based on the clustering of itcms, factor I was named "poor technical information" and factor 2 was named "cultural incompatibility". The two represent the major cultural-related factors constraining farmers use of cowpen technologies.

Specilic issues with high londings under poor technical information include lack of adequate technical knowledge in the use of improved cowpea technologies $(0.87)$, lack of contact with important information sources on improved cowpea technologies $(0.70)$ and complexity of improved cowpea technologies $(0.60)$. Agricultural technology transfer is a process with multiple functions which include information, teaching, technology supply and technology service (Asiabaka, 1991). This implies that the recipicints of the technology require technical knowledge that underlie the formulne and design technology (Okono, 1994). I lence, the poor teclnical know-how status of the farmers may contribule in making adoption of improved cowpea technologies dillicult.

Issues that loaded high under cultural incompatibility Include difficulty in Integrating technology into existing production systems $(0.72)$, poor storage of seeds of improved cowpea varieties $(0.61)$ and conflict between technology and the norms of the people $(0.47)$. In other words, improved cowpea technologies generated by research emphasized more of technological feasibility and economic viability through the use of high-yielding varieties with less empliasis on cultural compatibility with traditional norms and farming systems. While intercropping of cowpea with millet and/or sorghum or maize, with of without groundnut are the commonly practiced cropping systems of the farmers (Mortimore of al, 1997), initial cowpen improvements focused on the selection of genotypes that perform well in sole cropping. ^gain, the improved (early-maturing) varieties which mature at the peak of the rainy season make harvesting lideous and laborious for the farmers who are compelled at the expense of other activities, to visit the farms regularly to avoid licavy losses in the lield due to high moisture content of the seeds. 'This does not suit the farmers' production systems. Agricultural technology worthy of transfer should be compatible with the cultural domain of the people and hence the production clomain of the farmers slould be examined bofore introducing an innovation.

\section{liconomic Faclors}

Dala in Table 3 show the varimax rolated economicurelated fincors constrnining farmets" use of improved cowpea technologies. (In the hasis of item loadings, factor 1 was named "high cost of inputs" and factor 2 was named "unavailabilily of necessary inputs"

Issues with high loading under high cost of inputs include, high cost of acquiring/hiring tractors for land preparation $(0.82)$, high cost of available agro-chemicals (insecticides/fungicides/ herbicides) (0.69), high cost of improved cowpea seeds $(0.64)$, high cost of inorganic fertilizers $(0.58)$ and lack of finance to carryout farm operation associated with improved cowpen tecilnologies (0.56). In many circumstances the clevelopment of sustainable production requires increased use of purchased inputs such as seeds, fertilizers, pesticides and equipment. However, this also demands the availability of find; consequently the poor economic eondition of the farmers constrains them in using improved cowpea technologies

ltems which loaded high under unavailability of necessary inputs include difficulty in acquiring/hiring tractors for land preparation (0.64), unavailability of agrochemicals (insecticides/ fungicides/ herbicides) (0.55), difficulty in ac- 


\section{Table 3: Varimax Rotated Economic Factors Constraining Farmers' Use of Improved Cowpen Varieties}

\begin{tabular}{lcc}
\hline Economic-Related Variables & $\begin{array}{c}\text { lactor 1 } \\
\text { (Iligh Cost of } \\
\text { Inputs) }\end{array}$ & $\begin{array}{c}\text { Factor } 2 \\
\text { (Unavailability of } \\
\text { Necessary Inputs) }\end{array}$ \\
\hline $\begin{array}{l}\text { Lack of finance to carryout farm } \\
\text { operations associated will }\end{array}$ & 0.56 & 0.17 \\
$\begin{array}{l}\text { improved cowpen leclunologies. } \\
\text { Unavailability of improved cowpen }\end{array}$ & 0.17 & 0.52 \\
secds. \\
$\begin{array}{l}\text { Iligh cost of improved cowpen } \\
\text { seeds. }\end{array}$ & 0.64 & -0.06 \\
$\begin{array}{l}\text { Dilliculty in acquiring/hiring } \\
\text { tractors for land preparation. }\end{array}$ & 0.21 & 0.64 \\
$\begin{array}{l}\text { High cost of acquiring/hiring } \\
\text { tractors for land preparation. }\end{array}$ & 0.82 & -0.02 \\
$\begin{array}{l}\text { Scarcity of inorganic fertilizers. } \\
\text { High cost of inorganic fertilizers. }\end{array}$ & 0.42 & 0.44 \\
$\begin{array}{l}\text { Unavailability of agro-chemicals } \\
\text { (insecticides/fungicides/herbicides) } \\
\text { needed for spraying. }\end{array}$ & 0.58 & -0.02 \\
$\begin{array}{l}\text { High costs of available agro- } \\
\text { chemicals } \\
\text { (insecticides/fungicides/herbicides) } \\
\text { are costly. }\end{array}$ & -0.04 & 0.55 \\
\hline
\end{tabular}

quiring improved cowpea seeds $(0.52)$ and senrcity of inorganic lertilizers $(0,44)$, The unavailability of 'these inputs may ficustrato finmers' efforts in accepting improved cowpea technologies thereby constraining the overall effectiveness of technology transfer and adoption. In other words, the non-availability of these essential inputs can influence the farmer in many ways. For instance, while some fatmers imay not use the technologies at all; others may partially use the non-input components and reject the farm input aspects. Some other farmers may use the technologies and later reject or modify them in order to make allowance for the unavailable inputs. However, modification of recommended inputs may have negative or positive effects on the output of improved cowpea technologies.

\section{CONCLUSION}

The lindings of this study show that factors constraining farmers' use of improved cowpea technologies include land and labour problems, marketing problems and poor technical information. Others include, cultural incompatibility, high cost of inputs and unavailability of necessary inputs.

Institutional cowpea improvements directed at increasing yield of the farmers appear to have failed to adequately meet the needs and requirements of their physical (climate, soil, abiotic/biotic stresses) and socio-economic (economic status, user conccrns, consumer preferences, markets, etc.) environments. This suggests the need for researehers, policy makers and administrators of extension services to consicler seriously these issues which constitute limiting 
factors to increased cowpea production in the area.

\section{REFERENCES}

Agboola, S.D. (1980). The Role of Nigerian Stored Products Research Institute in Nigeria's March Towards Self Sulficiency in Food. Nigerian Stored Products Research Institute (NSPRI) Occasional Paper Series. No. 1.

Agwu, A.E. and Anyanwu, A.C. (1996) Sociocultural and Environmental Constraints in Implementing the NALDA Programme in Southeastern Nigeria: A case study of Abia and Enugu States. Journal of Agriculture, Technology and Education. Vol. 1 (2) pp. 68-72.

Anazonwu-Bello, J. N. (1976). Food and Nutrition in Practice. London: Macmillan Educational Limited.

Asiabaka,C.C. (1991). The Role of Imo State Agricultural Development Project in Boosting Food Production. The Nigerian Journal of Agricultural Extension. Vol.6 (1 and 2) pp. 47-51.

Child, D. (1978). The Essentials of Factor Analysis. New York: Holt Rinabart and Wistan Ltd.

Fadiji, T.O. Gefu, T.T and Adeniji, O.B. (1996). This is the Institute for Agricultural Research (IAR). $3^{\text {rd }}$ Edition. Publication and Information Unit, IAR Samaru, Zaria.

Federal Office of Statistics (1995). Annual Abstract of Statistics 1995 Edition. Federal Office of Statistics Lagos, Nigeria.

Federal Office of Statistics (1996). Annual Abstract of Statistics 1996 Edition. Federal Office of Statistics Lagos, Nigeria

Harkness, C., Awale, A. A. and Gillett, S.(1984).Cowpea and Research in Kano State, Nigeria, 1982-1984. A Paper Prepared for the World Cowpea Research Conference Held at IITA $4^{\text {th }}-9^{\text {th }}$ November 1984.
International Institute of 'Tropical Agriculture (IITA) (1993). Grain I egume Improve-

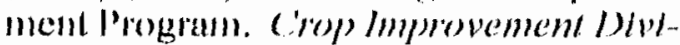
sion Activity Report and Work Plan. IITH , Ibadan, Nigeria.

Mnclukwe, M.C. (190), lincler Amulysis nis Research Design in Agricultural Extension. Journal of Agriculture, Techmology and Education. Vol.1 (2) pp 103-116.

Mortimore,J.M., Singh, B.B., Harris,F. and Blade,S.1. (1997). Cowpea in Traditional Cropping Systems In: Singh,B.B.; D.R. Mohan Raj, K.E. Dashiell and L.E.N. Jackai (eds.). Advances in Cowpea Research. Co-publication of IITA, and JIRCAS. IITA, Ibadan, Nigeria.

Okono, F.J.C. (1994). Technology Transfer and Industrial Development Technology Transfer in National Development. Proceedings of the $5^{\text {th }}$ National COIDR Iseminar. CODRI Occasional Paper No. 3.

Okuneye,P.A. (1994). Post Harvest Storage and Processing Technologies: Alternative Ways of Enhancing Food Supply in Lagos State. Centre for Rural Development, Lagos State University Ojo; Lagos.

Pierce, J.T. (1990). The Food Resource. New York :John Wiley and Sons.

Prince,M., Balasubramanian, V. and Cashahayo, D. (1986) Development of Improved Cowpea Varieties Suitable for Semi-arid Regions of Rwanda. Tropical Grain Legume Bulletin. World Cowpea Research Conference 5-9 November, 1986, Country Reports No. 32.

Quin,F.M.(1997). Introduction. In: Singh, B.B. D.R. Mohan Raj, K.E. Dashiell and L.E.N. Jackai (eds.). Advances in Cowpea Research. Co-publication of IITA, and JIRCAS. IITA, Ibadan, Nigeria.

Rachie, K.O. (1985). Introduction. In: S.R.Singh and K.O. Rachie (eds.). Cowpea Research, Production and Utilization. . New York: John Wiley and Sons.

Shaib,B., Aliyu,A. and Bakshi,J.S. (eds.). (1997). Agricultural Zones. Nigeria: National 
Agricultural Research Strategy Plan 1096 2010. Depnrment of $A$ pricullumenl

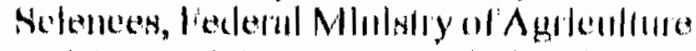
and Natural Resources, Abuja. Ibadan, Nigeria: Intec Printers Limited.

Singh, B.B and N'tare B.K.. (1985). Development. of Improved Cowpea Varieties in Africa. In: S.R Singh and K.O. Rachie (eds.). Cowpea Research, Production and Utilization. New York: John John Wiley and Sons. 